\title{
A case report of adrenocorticotropic hormone to treat recurrent focal segmental glomerular sclerosis post-transplantation and biomarker monitoring
}

\section{Siddiq Anwar ${ }^{1}$, Derek S. Larson ${ }^{1}$, Nima Naimi ${ }^{1}$, Muhammad Ashraf ${ }^{1}$, Nancy Culiberk ${ }^{1}$, Helen Liapis ${ }^{2}$, Changli Wei ${ }^{3}$, Jochen Reiser ${ }^{3}$ and Daniel C. Brennan ${ }^{1 *}$}

${ }^{1}$ Department of Medicine, Washington University School of Medicine, St. Louis, MO, USA

2 Department of Pathology, Washington University School of Medicine, St. Louis, MO, USA

${ }^{3}$ Department of Medicine, Rush University Medical Center, Chicago, IL, USA

\section{Edited by:}

Katsuhiko Asanuma, Kyoto University

Graduate School of Medicine, Japan

\section{Reviewed by:}

Gaurav Gupta, Virginia

Commonwealth University, USA

Christian Morath, University of

Heidelberg, Germany

*Correspondence:

Daniel C. Brennan, Department of Medicine, Renal Division, Washington University School of Medicine, Campus Box 8126, 660 S. Euclid Avenue, St. Louis, MO 63110, USA e-mail:dbrennan@dom.wustl.edu
Background: Recurrent focal segmental glomerular sclerosis (rFSGS) in renal transplant recipients (RTR) is difficult to predict and treat. Early rFSGS is likely from circulating factors and preformed antibodies.

Methods: We present the case of a 23-year-old white man who presented with rFSGS and acute renal failure, requiring dialysis 9-months after a 1-haplotype matched living-related transplant. We retrospectively analyzed serum samples from various clinical stages for rFSGS biomarkers: serum glomerular albumin permeability $\left(P_{\text {alb }}\right)$, soluble urokinase-type plasminogen activator receptor (suPAR) serum level with suPAR- $\beta 3$ integrin signaling on human podocytes, and angiotensin II type I receptor-antibody (AT1R-Ab) titer.

Results: All biomarkers were abnormal at 1-year pre-transplant prior to initiation of dialysis and at the time of transplant. After initiation of hemodialysis, $\beta 3$ integrin activity on human podocytes, in response to patient serum, as well as AT1R-Ab were further elevated. At the time of biopsy-proven recurrence, all biomarkers were abnormally high. One week after therapy with aborted plasmapheresis (secondary to intolerance), and high dose steroids, the $\mathrm{P}_{\mathrm{alb}}$ and suPAR- $\beta 3$ integrin activity remained significantly positive. After 12-weeks of treatment with high-dose steroids, rituximab, and galactose, the patient remained hemodialysis-dependent. Three-months after his initial presentation, we commenced adrenocorticotropic hormone (ACTH, Acthar ${ }^{\circledR}$ Gel), 80 units subcutaneously twice weekly. Four-weeks later, he was able to discontinue dialysis. After 8-months of maintenance ACTH therapy, his serum creatinine stabilized at $1.79 \mathrm{mg} / \mathrm{dL}$ with $<1 \mathrm{~g}$ of proteinuria.

Conclusion: ACTH therapy was associated with improvement in renal function within 4 weeks. The use of rFSGS biomarkers may aid in predicting development of rFSGS.

Keywords: acute kidney injury, albumin permeability factor, angiotensin 1 receptor antibody, podocyte, recurrent focal segmental glomerular sclerosis, soluble urokinase plasminogen activator receptor

\section{INTRODUCTION}

Renal allograft loss due to recurrence of idiopathic focal segmental glomerular sclerosis (rFSGS) is common, with an incidence of $30-50 \%(1-3)$. Recurrent FSGS has been reported within 1 week after transplant (4); and it has been hypothesized that a circulating factor is responsible $(5,6)$. Injecting laboratory animals with serum from patients with FSGS caused proteinuria and glomerular lesions reminiscent of FSGS (7). Serum from FSGS patients induced increased glomerular albumin permeability $\left(\mathrm{P}_{\mathrm{alb}}\right)$ in isolated glomeruli ex vivo (5). Savin et al. suggested that the permeability factor is a $50 \mathrm{kD}$ plasma protein (5), but the nature of this $\mathrm{P}_{\mathrm{alb}}$ factor is still undefined. The approximate $50 \mathrm{kD}$ sized serum soluble urokinase receptor (suPAR) is one of the leading candidates. Elevated serum levels of circulating suPAR (more than $3000 \mathrm{pg} / \mathrm{dL}$ ) have been proposed to confer heightened risk for rFSGS by inducing podocyte injury through activation of $\beta 3$-integrin (8). A recent report suggested antibodies to the angiotensin II type 1 receptor (AT1R-Ab) may contribute to development of rFSGS in renal transplant recipients (RTR) by causing podocyte injury and severe podocyte foot process effacement (9).

Our patient presented with rFSGS. Therefore, we analyzed three biomarkers in parallel and measured serum suPAR and the suPAR beta3-integrin axis after incubation of human podocytes with the patient's sera, $\mathrm{P}_{\mathrm{alb}}$, and AT1R-Ab serially in samples obtained 1year before transplant, at the time of transplant, when he was admitted with rFSGS and acute kidney injury 9-months after transplantation and 1- and 12-weeks after treatment.

Our patient did not respond or could not tolerate usual methods of treatment for rFSGS. Adrenocorticotropic hormone Acthar $^{\circledR}$ (Acthar Gel, Questcor, Anaheim Hills, CA, USA) has been 
shown to induce complete or partial remission in a percentage of patients with treatment-resistant FSGS in native kidneys, with 2 of 5 responders in one study and 8 of 24 responders in another (10, 11). We report the use of Acthar in this patient with rFSGS.

\section{SUBJECTS AND METHODS}

This study was approved by the Human Research Protection Office (HRPO) of Washington University School of Medicine. A 23year-old white male with a history of end stage renal disease (ESRD) secondary to FSGS presented 9-months after undergoing a one-haplotype matched renal transplant on 24 July 2012 from his father with a low-grade fever consistent with a nondescript viral illness, malaise, progressive edema, acute kidney injury, and nephrotic range proteinuria. The complement dependent cytotoxicity (CDC) and flow cross-match were negative pre-transplant.

At the time of his transplant surgery, he had received thymoglobulin $5 \mathrm{mg} / \mathrm{kg}$ over 3 days and was maintained on tacrolimus, enteric coated mycophenolic acid (MPA), and prednisone. There were no preformed donor specific antibodies. He developed lowlevel cytomegalovirus (CMV)-viremia (Table 1) and leukopenia 4-months after transplantation, and his MPA was discontinued and the valganciclovir (VGCV) dose increased from 450 to $900 \mathrm{mg}$ daily for treatment. Tacrolimus levels ranged $4-7 \mathrm{ng} / \mathrm{mL}$. His CMV-viremia resolved within 4 weeks (Table 1 ) and he was treated with consolidation therapy with VGCV, $900 \mathrm{mg}$ daily, which he was still taking at presentation.

\section{RESULTS}

Nine-months after his renal transplant, he presented with elevated serum creatinine from a baseline of $1.2-2.5 \mathrm{mg} / \mathrm{dL}$. His $24-\mathrm{h}$ urine protein excretion revealed $10 \mathrm{~g}$ of proteinuria. There were no donor specific antibodies identified by single antigen bead assay (Luminex, One-lambda, Los Angeles, CA, USA). His blood CMV-PCR was negative, and he had a normal renal transplant sonogram.

A renal allograft biopsy demonstrated 19 glomeruli, one of which was partially sclerosed and one was globally sclerosed (Figure 1A). There was one medium size artery with no arteritis. There was moderate arteriolar thickening. There was no tubulitis. Periodic acid-Schiff and trichrome stains confirmed acute tubular injury and highlighted minimal interstitial fibrosis. There was no evidence of thrombotic microangiopathy. Immunofluorescence staining was negative for $\mathrm{C} 4 \mathrm{~d}$ in peritubular capillaries. There was no peritubular capillaritis. Electron microscopy showed extensive foot process effacement and detached podocytes with reactive cytoplasmic changes and villiform transformation (Figure 1B). Abundant red blood cells (RBCs) were noted in the Bowman's space. The findings were consistent with rFSGS.

We analyzed stored blood samples from the Washington University Kidney Translational Research Core (NIH/NIDDK P30 DK079333) and tested for glomerular $\mathrm{P}_{\mathrm{alb}}$ (Savin Lab, Renal Research, Kansas City Veterans Administration Medical Center, Kansas City, MO, USA), suPAR, suPAR-beta 3 integrin ( $\beta 3$ integrin) signaling (Reiser Lab, U of ILL at Chicago, Chicago, IL, USA), and angiotensin II type I receptor-antibody (AT1R-Ab) (Immunogenetics Laboratory, Johns Hopkins University, Baltimore, MD,
USA) on samples from 1-year pre-transplant, at the time of transplant, and when the patient presented with acute kidney injury (Table 1). To overcome a possible confounder of elevated serum suPAR in the setting of reduced GFR, we also evaluated the activity of $\beta 3$ integrin signaling on cultured human podocytes incubated with the patient's sera. With this assay, strong integrin activation is indicative of the presence of pathologic suPAR forms, but not physiologic or inflammatory suPAR that accumulated from decreased clearance (12).

The levels of suPAR, suPAR- $\beta 3$ integrin activation, and $\mathrm{P}_{\mathrm{alb}}$ were elevated prior to transplant $(3573 \mathrm{pg} / \mathrm{mL}, 1.63$, and 0.77 , respectively) and at the time of recurrence $(4691 \mathrm{pg} / \mathrm{mL}, 1.99$, and 0.61 , respectively). suPAR values $>3500 \mathrm{pg} / \mathrm{mL}$ and $\beta 3$ integrin activity $>1.3-1.5$ are suggestive of suPAR- $\beta 3$ integrin mediated FSGS. A $\mathrm{P}_{\mathrm{alb}}$ of 0 is normal and values $>0.5$ designates an increased risk (non-specific if between 0.2 and 0.5). The level of AT1R-Ab was also increased prior to transplant, $20.4 \mathrm{U} / \mathrm{mL}$, but was borderline normal at $16.8 \mathrm{U} / \mathrm{mL}$ at the time of recurrence. AT1R-Ab is presumed to be negative when $<10$, borderline when $10-17$, and positive when $>17$ (Table 2 ).

The patient was started on methylprednisolone $500 \mathrm{mg}$ daily for three days (Figure 2). Plasmapheresis with 1.5 plasma volume exchanges with fresh frozen plasma followed by $10 \mathrm{~g}$ of IVIG the day of his renal biopsy was attempted. However, shortly after commencement, the patient developed wheezing, shortness of breath, and an erythematous rash on his trunk, and extremities suggestive of an allergic reaction, and plasmapheresis was discontinued. The next day we attempted plasmapheresis with albumin, and again the patient developed similar symptoms. We considered plasmapheresis with a hypoallergenic dialyzer column, but he refused this treatment. We administered rituximab $200 \mathrm{mg}$ intravenously, once. This low-dose was chosen because of our experience with efficacy with this dose for other recurrent glomerulonephritidies and others have reported that even $100 \mathrm{mg}$ can successfully treat recurrent FSGS (13-16).

Five-days after the initial presentation, the patient became anuric and he required hemodialysis (Figure 2). We initiated lisinopril and arranged for outpatient hemodialysis. We attempted to treat him with galactose $(15 \mathrm{~g}$ of galactose twice a day for 6 weeks) in view of previously published data on possible benefit $(17,18)$. Unfortunately, the galactose had to be discontinued after 4 -weeks due to severe diarrhea. He subsequently received oral prednisone $100 \mathrm{mg}$ daily as he had responded to a similar dose during his previous four FSGS recurrences as a child prior to his renal transplantation. At the end of 8-weeks, the patient was still hemodialysis-dependent and the prednisone was gradually tapered to $10 \mathrm{mg}$ daily over 2 months. We reassessed the three circulatory factors. His $\mathrm{P}_{\text {alb }}$ was 0.43 ( 0 is normal), his suPAR was $3447.9 \mathrm{pg} / \mathrm{mL}$ (negative $<3000 \mathrm{pg} / \mathrm{mL}, \beta 3$ integrin activity was not available due to sample unavailability), and AT1R-Ab level was $9.3 \mathrm{U} / \mathrm{mL}$ (negative $<10 \mathrm{U} / \mathrm{mL}$ ).

Due to the significant side effects of prednisone, persistent renal failure, and lack of efficacy, we initiated ACTH treatment (Acthar ${ }^{\circledR} \mathrm{Gel}$ ), 80 units twice weekly at 3.5-months after his initial presentation (11). One-month after initiation of ACTH treatment, the urine output increased, creatinine improved, and the patient was able to discontinue dialysis. After 8-months on this therapy, 
Table 1 | Time course of clinical events, laboratory results and biomarkers

\begin{tabular}{|c|c|c|c|c|c|c|c|c|c|c|c|}
\hline & $\begin{array}{c}1 \text { year } \\
\text { pre- } \\
\text { transplant }\end{array}$ & $\begin{array}{c}\text { At } \\
\text { transplant }\end{array}$ & $\begin{array}{c}1 \text { month } \\
\text { post- } \\
\text { transplant }\end{array}$ & $\begin{array}{c}3 \text { months } \\
\text { post- } \\
\text { transplant }\end{array}$ & $\begin{array}{l}4 \text { months } \\
\text { post- } \\
\text { transplant }\end{array}$ & $\begin{array}{c}9 \text { months } \\
\text { post- } \\
\text { transplant } \\
\text { (admitted } \\
\text { with AKI) }\end{array}$ & $\begin{array}{l}1 \text { week after } \\
\text { admission } \\
\text { (after pulse } \\
\text { steroids } \\
\text { and one PE) }\end{array}$ & $\begin{array}{c}12 \text { months } \\
\text { post- } \\
\text { transplant } \\
\text { (2 weeks before } \\
\text { starting ACTH) }\end{array}$ & $\begin{array}{l}15 \text { months } \\
\text { post- } \\
\text { transplant } \\
\text { (2.5 months } \\
\text { on ACTH) }\end{array}$ & $\begin{array}{c}18 \text { months } \\
\text { post- } \\
\text { transplant } \\
\text { (5 months } \\
\text { on ACTH) }\end{array}$ & $\begin{array}{c}28 \text { months } \\
\text { post- } \\
\text { Transplant } \\
\text { (8 months after } \\
\text { ACTH therapy) }\end{array}$ \\
\hline Creatinine (mg/dL) & 4.09 & $\mathrm{HD}$ & 1.3 & 1.2 & 1.2 & $\mathrm{HD}$ & $\mathrm{HD}$ & $\mathrm{HD}$ & 2.9 & 2.3 & 1.83 \\
\hline FK trough $(\mathrm{ng} / \mathrm{mL})$ & - & - & 6.4 & 6 & 5.8 & - & - & 5.6 & 3.4 & 1.6 & 2.4 \\
\hline CMV PCR (copies/mL) & - & - & - & 4533 & $<200$ & $<200$ & - & - & ND & ND & ND \\
\hline$B K$ virus $P C R$ & - & - & - & ND & - & ND & - & - & ND & ND & ND \\
\hline Albumin (g/dL) & 4.9 & 4.5 & 4.7 & 4.9 & 4.7 & 3.1 & 2.5 & 2.6 & 3.6 & 4.4 & 4.8 \\
\hline $\mathrm{P} / \mathrm{C}$ ratio & - & - & 0.09 & - & - & 17.7 & - & - & 7.2 & 2.2 & 0.34 \\
\hline DSA & - & ND & - & ND & - & ND & - & ND & - & - & - \\
\hline$P_{\mathrm{alb}}$ & 0.77 & 0.51 & - & - & - & 0.61 & 0.58 & 0.43 & - & - & - \\
\hline SuPAR $(p g / m L)$ & 3573 & 2898 & - & - & - & 4691 & 4428 & 3447.8 & - & - & - \\
\hline AT1R antibody (U/mL) & 20.4 & 23.2 & - & - & - & 16.8 & 13.5 & 9.3 & - & - & - \\
\hline
\end{tabular}

AKI, acute kidney injury; HD, hemodialysis; CMV, cytomegalovirus; IgG, immunoglobulin G; PCR, polymerase chain reaction; PE, plasma exchange; ND, not detected; FK, tacrolimus; P/C, protein to creatinine ratio; $D S A$, donor specific antibodies; NA, not applicable; sUPAR, soluble urokinase receptor.

Suspicious: $>3000 \mathrm{pg} / \mathrm{mL}$, values $>3500 \mathrm{pg} / \mathrm{mL}$ are suggestive of suPAR-mediated FSGS (Dr. Reiser's Lab, Rush University, USA). Palb: glomerular albumin permeability factor. Normal: 0. Nonspecific: 0.2-0.5. Increased risk: >0.5 (Renal Research, KC VA Medical Center, Kansas City, MO, USA). Angiotension-1 receptor antibody: AT1Rab. Negative: <10. Borderline: 10-17. Positive: >17 (Immunogenetics Laboratory, The Johns Hopkins University, Baltimore, MD, USA). 


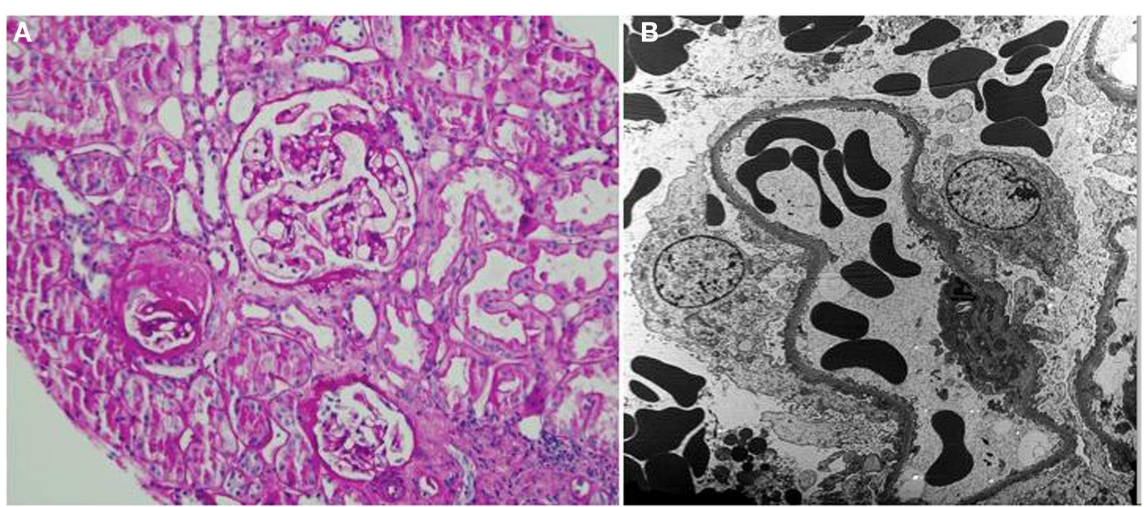

FIGURE 1 | (A) Periodic acid-Schiff stain shows one partially sclerotic glomerulus and two intact glomeruli; there is no tubulitis or interstitial fibrosis; minor tubular epithelial cell changes are noted $(\times 200)$. (B) Electron microscopy shows foot process effacement (approximately $30 \%$ of the surface area) and reactive cytoplasmic changes in podocytes. Numerous red blood cells are present in the capillary loops and Bowman's space $(\times 3000)$.

Table 2 | Interpretation of putative markers in FSGS.

Soluble urokinase receptor: suPAR

Relative podocyte $\beta 3$ integrin activity/paxillin $\quad<1$ on human podocytes compared to control (10\% patient sera)

Glomerular albumin permeability factor: $P_{\text {alb }}$ Angiotension-1 receptor antibody: AT1Rab
Normal: undetermined

Normal: 0

Negative: $<10 \mathrm{U} / \mathrm{mL}$
Intermediate risk:

$>3000 \mathrm{pg} / \mathrm{mL}$

Intermediate risk: $>1$
Suggestive of suPAR-mediated FSGS: $>3500 \mathrm{pg} / \mathrm{mL}$

Highly suggestive of suPAR- $\beta 3$ integrin mediated FSGS: > 1.5

Non-specific: $0.2-0.5$

Increased risk: $>0.5$

Borderline: $10-17 \mathrm{U} / \mathrm{mL} \quad$ Positive: $>17 \mathrm{U} / \mathrm{mL}$

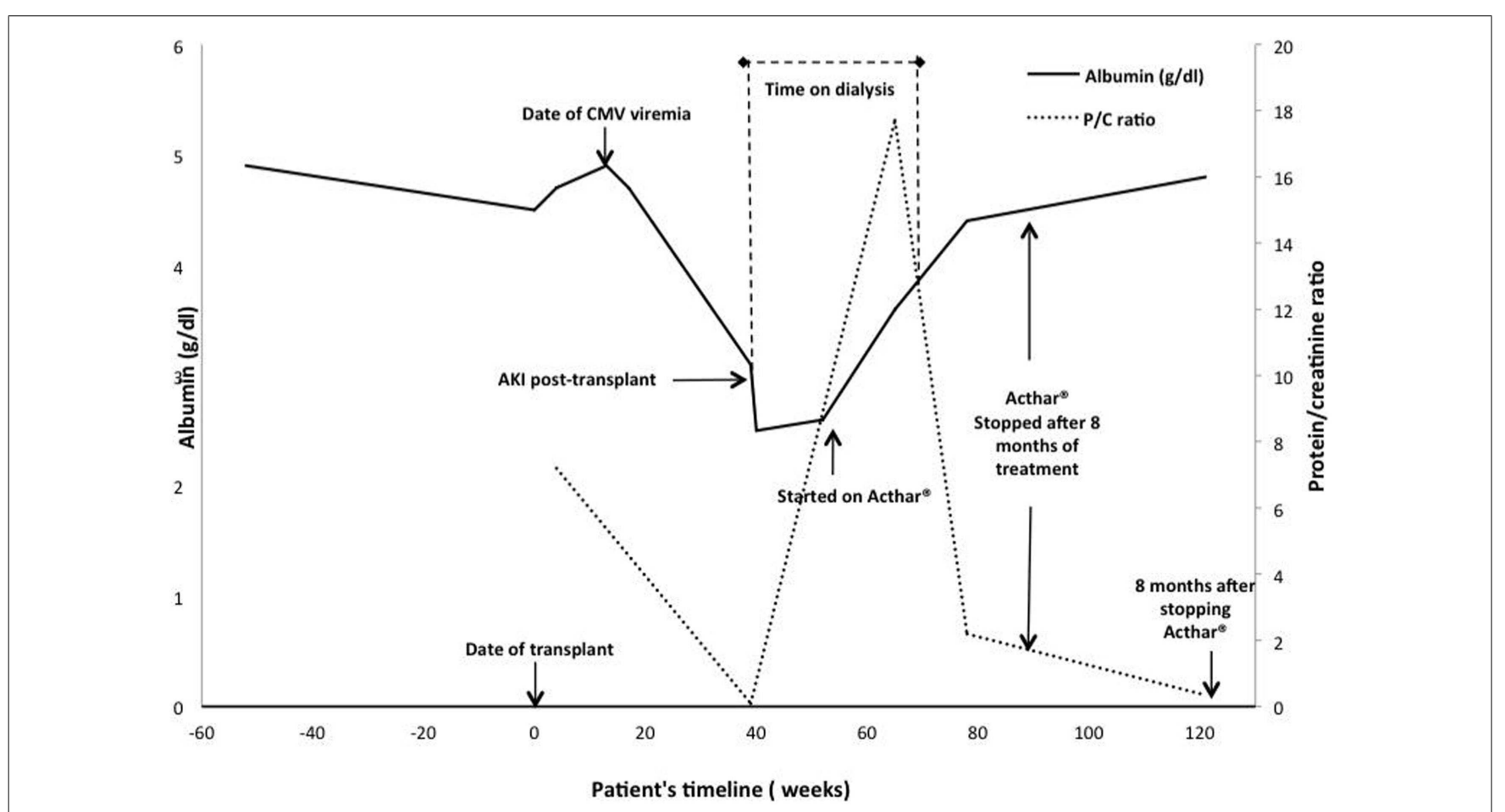

FIGURE 2 |Time course of events, treatments, and responses in serum albumin and urine protein excretion. The serum albumin level over time is depicted by the solid black line and the urine protein/creatinine ratio by the dashed gray line. The value at 40 weeks was imputed to be 0 because the patient was anuric. 
his creatinine decreased and remained stable at $2.0-2.5 \mathrm{mg} / \mathrm{dL}$. His serum albumin improved from 2.6 to $4.6 \mathrm{~g} / \mathrm{dL}$ and his urine protein-creatinine ratio decreased from 17.7 to 1.2. The ACTH was discontinued. At last follow up, 28 months after transplant and 8 months after discontinuation of ACTH, the serum creatinine was $1.83 \mathrm{mg} / \mathrm{dL}$, and a urine protein creatinine ratio was 0.34 , and his serum albumin is $4.8 \mathrm{mg} / \mathrm{dL}$ (Figure 2).

\section{DISCUSSION}

Various factors have been implicated as etiologic for rFSGS and include suPAR (8), $\mathrm{P}_{\mathrm{alb}}$ (5), and AT1R-Ab (9). This case documents rFSGS in a renal transplant recipient in whom the levels of suPAR- $\beta 3$ integrin signaling, $\mathrm{P}_{\mathrm{alb}}$, and AT1R-Ab were measured in combination and serially; starting from the pre-transplant period through recurrence and follow up. At the time of transplant, the $\mathrm{P}_{\mathrm{alb}}$ and AT1R-Ab and podocyte $\beta 3$ integrin activity were elevated, which means that podocyte $\beta 3$ integrin was elevated in focal adhesions (represented by paxillin staining), the contact points of podocytes with the extracellular matrix (12). These biomarkers identified the patients as high risk for rFSGS despite the fact that he remained recurrence free for the first 9months following his transplant. It will require further studies to understand why the patient was disease free for the first 9-months after transplant. The use of rabbit anti-thymocyte globulin (rATG) for induction may have contributed as rATG has been associated with less rFSGS (19). Of note, rabbit-ATG is no longer detectable in blood 6-9 months after administration - the time of the recurrence in the face of persistently high putative biomarkers for rFSGS (20).

The role of suPAR in proteinuric renal disease is currently under active investigation (21). It may be possible that suPAR plays a role in both genetic and non-genetic forms of rFSGS (9); even so rFSGS is generally less prominent in genetic forms of FSGS (8). Some reports show inconsistencies in associations of suPAR and rFSGS in patients with advanced CKD and reduced eGFR in pediatric $(22,23)$ and adult FSGS patients (24).

Some of the inconsistencies between reports may be related to the quality of the stored samples and the availability of all relevant clinical information including renal biopsy. It is also likely that different suPAR fragments exist and that all of those may not be readily measured with current ELISA, and thus the need to detect the activating capacity of suPAR at the level of the podocyte. In addition, urinary suPAR was recently shown to be highly specific for FSGS and FSGS-urine strongly activated $\beta 3$ integrin on human podocytes $(25,26)$. In the future, urinary suPAR measurements in urine may provide valuable information in assaying the suPAR forms that are most relevant to FSGS.

Savin et al. reported a method to test for increased glomerular capillary permeability after incubation with potentially injurious agents or with medium containing $2 \% \mathrm{vol} / \mathrm{vol}$ patient serum. The permeability activity (termed $\mathrm{P}_{\mathrm{alb}}$ activity or $\mathrm{P}_{\mathrm{alb}}$ ) is used to infer the presence of a circulating factor. $\mathrm{P}_{\mathrm{alb}}$ is calculated from the ratio of capillary expansion of experimental and control glomeruli. Values range from 0 , indicating no activity, to 1 , indicating complete loss of the permeability barrier. Values $>0.5$ have been associated with a high incidence of rFSGS following RTR (5). This permeability factor has a high affinity for galactose and $\mathrm{P}_{\text {alb }}$ activity was lost after galactose infusion in a RTR with rFSGS (17).
Our patient had elevated AT-1R Abs throughout his course. Podocytes express AT-1R $(27,28)$, and antibodies against the AT1R have been hypothesized to play a role in many kidney diseases. They have been shown to be elevated in vascular rejection (29), pre-eclampsia (30), and systemic sclerosis (31). The elevated levels suggest a possible role of AT1R-Ab in podocyte injury. In one case report of rFSGS, AT1R-Ab level was elevated and the patient was treated successfully with plasmapheresis and angiotensin converting enzyme inhibitors (ACEI) (9). While the clinical improvement of the patient after plasmapheresis suggests removal of antibodies, it does not prove the pathogenicity of AT1R-Ab in this case.

Our report provides valuable insights into the use of ACTH to treat rFSGS. Adrenocorticotropic hormone is a drug which has been approved for infantile spasms, but also carries the indication for nephrotic syndrome (32). Its use in renal transplant patients has not been reported for recurrent nephrotic syndrome. Although not completely defined, ACTH, either alone or via its breakdown product $\alpha$-melanocyte-stimulating hormone, may induce a potent anti-inflammatory effect by reducing B- and Tcell activity and may also have a direct, podocyte-sparing effect within the glomerulus (33). This would be consistent with the observation that serum suPAR and the integrin activation profile were decreasing. We were able to discontinue the ACTH after 8months of therapy without evidence of recurrence 8-months after discontinuation.

There are several limitations to our study. The study is retrospective and based on stored serum samples. As such, some level of sample deterioration is possible. We also did not have sufficient serum to assess our complete biomarker panel between transplant and recurrence and we did not have samples for biomarker assessment at the time of ACTH effectiveness. Lastly, we cannot validate the sensitivity, specificity, and variability of these assays.

In conclusion, this case of rFSGS suggests that elevated suPAR$\beta 3$ integrin signaling, $\mathrm{P}_{\mathrm{alb}}$, and AT1rab levels at pre-transplant confer an increased risk of developing rFSGS. This risk assessment is consistent with previously reported studies (12). However, the case also demonstrates the difficulty in understanding the precise cause as well as the course of rFSGS. Our patient developed recurrence 9 -months later when serum suPAR increased by more than $50 \%$. This could have been the initiating injury that caused a point of no return for podocyte injury.

Measuring suPAR and $\mathrm{P}_{\mathrm{alb}}$ levels in young transplant recipients with a history of FSGS in their native kidneys and/or when planning for living transplants might provide additional information to develop immunosuppression strategies and to optimize post-transplant monitoring.

Adrenocorticotropic hormone therapy provides transplant physicians with an additional therapeutic option for proteinuric kidney disease. Given the success in this case, the relationship of adrenocorticotropic hormone therapy and suPAR needs to be better defined on a molecular level as well as in controlled trials, possibly as an ad hoc to the trial currently underway for transplant glomerulopathy (34).

\section{ACKNOWLEDGMENTS}

This research was supported in part by NIH/NIDDK P30 DK079333 and K24DK002886-11, the Alan A. and Edith L. Wolff 
endowment, the generous support of Eileen M. Brooks and Donald F. Roach to DB and DK089394, DK073495, and DK101350 to JR. The authors would also like to acknowledge the laboratory expertise of Mukut Sharma and Dr. Virginia Savin at the Veterans Administration Hospital in Kansas City and Drs. Sian Eng and Nada Alachkar at Johns Hopkins University School of Medicine.

\section{REFERENCES}

1. Pinto J, Lacerda G, Cameron JS, Turner DR, Bewick M, Ogg CS. Recurrence of focal segmental glomerulosclerosis in renal allografts. Transplantation (1981) 32:83-9. doi:10.1097/00007890-198108000-00001

2. Chadban S. Glomerulonephritis recurrence in the renal graft. J Am Soc Nephrol (2001) 12:394-402.

3. Choy BY, Chan TM, Lai KN. Recurrent glomerulonephritis after kidney transplantation. Am J Transplant (2006) 6:2535-42. doi:10.1111/j.1600-6143.2006. 01502.x

4. Tejani A, Stablein DH. Recurrence of focal segmental glomerulosclerosis posttransplantation: a special report of the North American pediatric renal transplant cooperative study. J Am Soc Nephrol (1992) 2:S258-63.

5. Savin VJ, Sharma R, Sharma M, Mccarthy ET, Swan SK, Ellis E, et al. Circulating factor associated with increased glomerular permeability to albumin in recurrent focal segmental glomerulosclerosis. N Engl J Med (1996) 334:878-83. doi:10.1056/NEJM199604043341402

6. McCarthy ET, Sharma M, Savin VJ. Circulating permeability factors in idiopathic nephrotic syndrome and focal segmental glomerulosclerosis. Clin J Am Soc Nephrol (2010) 5:2115-21. doi:10.2215/CJN.03800609

7. Avila-Casado Mdel C, Perez-Torres I, Auron A, Soto V, Fortoul TI, HerreraAcosta J. Proteinuria in rats induced by serum from patients with collapsing glomerulopathy. Kidney Int (2004) 66:133-43. doi:10.1111/j.1523-1755.2004. 00715.x

8. Wei C, Trachtman H, Li J, Dong C, Friedman AL, Gassman JJ, et al. Circulating suPAR in two cohorts of primary FSGS. J Am Soc Nephrol (2012) 23:2051-9. doi:10.1681/ASN.2012030302

9. Alachkar N, Gupta G, Montgomery RA. Angiotensin antibodies and focal segmental glomerulosclerosis. N Engl J Med (2013) 368:971-3. doi:10.1056/ NEJMc1207233

10. Bomback AS, Canetta PA, Beck LHJ, Ayalon R, Radhakrishnan J, Appel GB. Treatment of resistant glomerular diseases with adrenocorticotropic hormone gel: a prospective trial. Am J Nephrol (2012) 36:56-8. doi:10.1159/000339287

11. Hogan J, Bomback AS, Mehta K, Canetta PA, Rao MK, Appel GB, et al. Treatment of idiopathic FSGS with adrenocorticotropic hormone gel. Clin J Am Soc Nephrol (2013) 8:2072-8. doi:10.2215/CJN.02840313

12. Wei C, El Hindi S, Li J, Fornoni A, Goes N, Sageshima J, et al. Circulating urokinase receptor as a cause of focal segmental glomerulosclerosis. Nat Med (2011) 17:952-60. doi:10.1038/nm.2411

13. Ponticelli C, Glassock RJ. Posttransplant recurrence of primary glomerulonephritis. Clin J Am Soc Nephrol (2010) 5(12):2363-72. doi:10.2215/CJN. 06720810

14. Fornoni A, Sageshima J, Wei C, Merscher-Gomez S, Aguillon-Prada R, Jauregui $\mathrm{AN}$, et al. Rituximab targets podocytes in recurrent focal segmental glomerulosclerosis. Sci Transl Med (2011) 3:85ra46. doi:10.1126/scitranslmed.3002231

15. Cho JH, Lee JH, Park GY, Lim JH, Kim JS, Kang YJ, et al. Successful treatment of recurrent focal segmental glomerulosclerosis with a low dose rituximab in a kidney transplant recipient. Ren Fail (2014) 36:623-6. doi:10.3109/0886022X. 2014.882238

16. Spinner ML, Bowman LJ, Horwedel TA, Delos Santos RB, Klein CL, Brennan DC. Single-dose rituximab for recurrent glomerulonephritis post-renal transplant. Am J Nephrol (2015) 41:37-47. doi:10.1159/000371587

17. Savin VJ, Mccarthy ET, Sharma R, Charba D, Sharma M. Galactose binds to focal segmental glomerulosclerosis permeability factor and inhibits its activity. Transl Res (2008) 151:288-92. doi:10.1016/j.trsl.2008.04.001

18. De Smet E, Rioux JP, Ammann H, Deziel C, Querin S. FSGS permeability factorassociated nephrotic syndrome: remission after oral galactose therapy. Nephrol Dial Transplant (2009) 24:2938-40. doi:10.1093/ndt/gfp278

19. Pascual J, Mezrich JD, Djamali A, Leverson G, Chin LT, Torrealba J, et al. Alemtuzumab induction and recurrence of glomerular disease after kidney transplantation. Transplantation (2007) 83:1429-34. doi:10.1097/01.tp.0000264554. 39645.74
20. Regan JF, Lyonnais C, Campbell K, Smith LV, Buelow R, US Thymoglobulin Multi-Center Study Group. Total and active thymoglobulin levels: effects of dose and sensitization on serum concentrations. Transpl Immunol (2001) 9:29-36. doi:10.1016/S0966-3274(01)00048-X

21. Trachtman H. suPAR and team nephrology. BMC Med (2014) 12:82. doi:10. 1186/1741-7015-12-82

22. Bock ME, Price HE, Gallon L, Langman CB. Serum soluble urokinase-type plasminogen activator receptor levels and idiopathic FSGS in children: a singlecenter report. Clin J Am Soc Nephrol (2013) 8:1304-11. doi:10.2215/CJN. 07680712

23. Peng Z, Mao J, Chen X, Cai F, Gu W, Fu H, et al. Serum suPAR levels help differentiate steroid resistance from steroid-sensitive nephrotic syndrome in children. Pediatr Nephrol (2014) 30(2):301-7. doi:10.1007/s00467-014-2892-6

24. Schlondorff D. Are serum suPAR determinations by current ELISA methodology reliable diagnostic biomarkers for FSGS? Kidney Int (2014) 85:499-501. doi:10.1038/ki.2013.549

25. Franco Palacios CR, Lieske JC, Wadei HM, Rule AD, Fervenza FC, Voskoboev $\mathrm{N}$, et al. Urine but not serum soluble urokinase receptor (suPAR) may identify cases of recurrent FSGS in kidney transplant candidates. Transplantation (2013) 96:394-9. doi:10.1097/TP.0b013e3182977ab1

26. Huang J, Liu G, Zhang YM, Cui Z, Wang F, Liu XJ, et al. Urinary soluble urokinase receptor levels are elevated and pathogenic in patients with primary focal segmental glomerulosclerosis. BMC Med (2014) 12:81. doi:10.1186/1741-701512-81

27. Liebau MC, Lang D, Bohm J, Endlich N, Bek MJ, Witherden I, et al. Functional expression of the renin-angiotensin system in human podocytes. Am J Physiol Renal Physiol (2006) 290:F710-9. doi:10.1152/ajprenal.00475.2004

28. Nijenhuis T, Sloan AJ, Hoenderop JG, Flesche J, Van Goor H, Kistler AD, et al. Angiotensin II contributes to podocyte injury by increasing TRPC6 expression via an NFAT-mediated positive feedback signaling pathway. Am J Pathol (2011) 179:1719-32. doi:10.1016/j.ajpath.2011.06.033

29. Dragun D, Muller DN, Brasen JH, Fritsche L, Nieminen-Kelha M, Dechend $\mathrm{R}$, et al. Angiotensin II type 1-receptor activating antibodies in renal-allograft rejection. N Engl J Med (2005) 352:558-69. doi:10.1056/NEJMoa035717

30. Zhou CC, Zhang Y, Irani RA, Zhang H, Mi T, Popek EJ, et al. Angiotensin receptor agonistic autoantibodies induce pre-eclampsia in pregnant mice. Nat Med (2008) 14:855-62. doi:10.1038/nm.1856

31. Riemekasten G, Philippe A, Nather M, Slowinski T, Muller DN, Heidecke H, et al. Involvement of functional autoantibodies against vascular receptors in systemic sclerosis. Ann Rheum Dis (2011) 70:530-6. doi:10.1136/ard.2010.135772

32. H.P. Acthar Gel Prescribing Information. Hayward, C.Q.P.I. (0000). Available from: http://www.actharhcp.com/proteinuria-in-nephrotic-syndrome/ acthar-and-proteinuria-in-nephrotic-syndrome.html

33. Bomback AS, Radhakrishnan J. Treatment of nephrotic syndrome with adrenocorticotropic hormone (ACTH). Discov Med (2011) 12:91-6.

34. Akkina S. Acthar as Rescue Therapy for Transplant Glomerulopathy in Kidney Transplant Recipients. (2014). ClinicalTrials.gov Identifier: NCT02057523.

Conflict of Interest Statement: Jochen Reiser is the inventor on pending and issued patents on novel anti-proteinuric therapies and technologies. He stands to gain royalties from their commercialization. All other authors declare that they have no relevant financial interests. The results of this paper have not been published previously in whole or part, except in abstract form. It is not under consideration for publication elsewhere.

Received: 08 January 2015; accepted: 27 February 2015; published online: 20 March 2015.

Citation: Anwar S, Larson DS, Naimi N, Ashraf M, Culiberk N, Liapis H, Wei C, Reiser J and Brennan DC (2015) A case report of adrenocorticotropic hormone to treat recurrent focal segmental glomerular sclerosis post-transplantation and biomarker monitoring. Front. Med. 2:13. doi: 10.3389/fmed.2015.00013

This article was submitted to Nephrology, a section of the journal Frontiers in Medicine. Copyright (c) 2015 Anwar, Larson, Naimi, Ashraf, Culiberk, Liapis, Wei, Reiser and Brennan. This is an open-access article distributed under the terms of the Creative Commons Attribution License (CC BY). The use, distribution or reproduction in other forums is permitted, provided the original author(s) or licensor are credited and that the original publication in this journal is cited, in accordance with accepted academic practice. No use, distribution or reproduction is permitted which does not comply with these terms. 